Heilna du Plogy

\title{
Stromings, sosiokodes en representasies
}

\begin{abstract}
In this article the concept of the sociocode, as described and used by Fokkema (1984), is used to describe the characteristic way of representation in modernist texts. Representation in literature is explained as the result of a specific set of perceptions which are individually as well culturally determined. From the discussion of the sociocode of Modernism, the conclusion is made that modernist texts do not represent: these texts are presentations, they are primarily concerned with their own ontology. In conclusion the similarities between Modernism as a literary movement in Western Europe and the work of the Sestigers in Afrikaans are indicated. It is suggested that these similarities should be investigated in more detail.
\end{abstract}

\section{Inleiding}

Om 'n stroming in die literatuur te beskryf, te definieer of af te baken, is ' $n$ moeilike onderneming. Literêre strominge of bewegings is nie eksakte en wetenskaplik afbakenbare entiteite nie en literêre tekste as sodanig bied weerstand teen rigiede klassifikasie, etikettering en kompartementalisering. Die beskrywing van 'n stroming is die taak van die literatuurgeskiedskrywing. Dit gaan daarin nie om 'n atomistiese beskrywing van geïsoleerde tekste nie, maar om 'n omvattende benadering waarin 'n verskeidenheid faktore 'n rol speel.

Uit tekste self, uit historiese gegewens oor outeurs en die idiolekte van outeurs, uit algemene historiese, sosiale en ekonomiese omstandighede, uit 'n rekonstruksie van ' $n$ bepaalde Zeitgeist, moet inligting bekom word om die aard en eienskappe van 'n stroming te probeer bepaal.

Een van die faktore wat deurgaans in gedagte gehou moet word, is dat die gegewens wat beskikbaar is aangaande die literatuur, die geskiedenis, die 
ekonomie, ensovoorts dikwels uit verskillende vakwetenskaplike paradigmas kom. (Die term paradigma word hier gebruik soos in die wetenskapskritiek van T.S. Kuhn waar dit dui op 'n geheel van konsepte, metodes en toepassings wat gedeel word deur 'n groep wetenskaplikes in 'n bepaalde periode ten opsigte van 'n bepaalde terrein van wetenskaplike ondersoek.)

In die literatuurgeskiedskrywing en in die literatuurstudie speel vakfilosofiese vertrekpunte 'n belangrike rol. Die plasing van die klem op of die outeur, of die teks, of die leser in 'n bepaalde studie, is telkens die resultaat van 'n wetenskapsbeskouing wat op sy beurt weer met 'n bepaalde filosofiese denkwyse saamhang. Gegewens uit verskillende literêr-teoretiese benaderinge kan wel saam gebruik word, maar dit bly noodsaaklik dat die onderliggende benadering nagegaan en verreken moet word wanneer die gegewens in 'n ander model gebruik word.

Volgens Fokkema (1984: 4-5) word die literatuurgeskiedskrywer in die beskrywing van 'n stroming gekonfronteer met 'n literêre verskynsel wat nie beskryf of verduidelik kan word deur eksklusief of hoofsaaklik op outeur of teks of ontvanger te fokus nie.

Fokkema (1984) stel voor dat 'n omvattende benadering gevolg word, wanneer gepoog word om 'n literêre stroming te beskryf. Die gedagte van 'n literêre sisteem soos deur die Russiese Formaliste beskryf, is vir hom aanvaarbaar omdat dit die moontlikheid bied om 'n verskeidenheid van literêr-relevante faktore in die beskrywing van ' $n$ stroming te inkorporeer. Die Russiese Formaliste het die literêre sisteem beskryf deur na stilistiese en komposisionele eienskappe van tekste te kyk. Op grond van die ooreenstemmende eienskappe en tegnicke is tekste dan as behorende tot 'n bepaalde sisteem beskou. Hulle sien die literatuurgeskiedenis as 'n opeenvolging van sisteme. Die normsisteme ontwikkel diachronies en word bepaal deur die komposisionele en tematiese konvensies wat ook die produksie en die resepsie van die tekste bepaal.

\subsection{Sosiokode en stroming}

Die konsep van 'n literêre sisteem soos aanvanklik deur Tynjanov omskryf, is veral deur die Sowjet-semiotiek verfyn en gespesifiseer. Fokkema (1984: 5-8) beskryf 'n sisteem van konvensies as 'n kode. Hy sluit aan by Lotman wat 'n kode defmieer as "a closed set of meaningful units and rules governing their combination, rules which allow for the transmission of certain messages" (Fokkema, 1984: 5).

Daar is vanselfsprekend verskillende kodes wat in literêre tekste 'n rol speel. Lotman onderskei tussen linguistiese en literêre kodes waar die literêre kodes 
supralinguaal is en taalgrense oorskry omdat dit geld in verskillende tale. Daar moet rekening gehou word met sowel die sintaktiese komponent wat met die kombinasie en organisasie van elemente te make het as met die semantiese komponent wat met die totstandkoming en uitbreiding van betekenis te make het. Verder speel die pragmatiese komponent van kodes, wat met die gebruiksomstandighede en kommunikasievoorwaardes te make het, ook 'n belangrike rol (Fokkema, 1984: 7).

Fokkema (1984: 8) onderskei vyf kodes wat volgens hom werksaam is in die meeste literêre tekste en stel voor dat 'n literêre stroming aan die hand van hierdie vyf kodes beskryf kan word:

1. the linguistic code, which, for example, directs the reader to read the text as an English text;

2. the literary code, which predisposes the reader to read the text as a literary text, i.e. a text with a high degree of coherence, with obvious consequences for the production and acceptability of connotations and metaphors;

3. the generic code, which instructs the reader to activate certain expectations and to suppress others, depending on the genre that has been chosen;

4. the period code or group code, which directs the reader to activate his knowledge of the conventions of a period or particular semiotic community;

5. the idiolect of the author, which, insofar as it is distinguished on the basis of recurrent features, also has the character of a code.

Hierdie vyf kodes bestaan onderling in verhouding tot mekaar sodat bulle in die teks mekaar onderling bepaal en beperk. Daar kan nog ander kodes ook wees, maar Fokkema identifiseer hierdie vyf as voldoende vir die beskrywing van 'n stroming. Hy gebruik die begrip sosiokode, waarin die vyf genoemde kodes geïnorporeer is, as vertrekpunt en omskryf die sosiokode as "the code designed by a group of writers often belonging to a particular generation, literary movement or current and acknowledged by their contemporary and later readers. Together, these writers and their readers form a semiotic community in the sense that the latter understand the texts produced by the former" (Fokkema, 1984: 11).

Fokkema gebruik die begrip sosiokode nogtans baie versigtig om die moontlikheid van rigiditeit of oorvereenvoudiging uit te skakel. Daar kan hoogstens onderneem word om literêr-historiese verskynsels te beskryf "with reference to more or less dominant sociocodes" (Fokkema, 1984: 12).

Dit is belangrik dat die sosiokode afhanklik is van die ontvangersreaksie. Die vernuwing en verandering in die literatuur word deur die lesersgemeenskap waargeneem en begryp en so kom die teks en die kode tot stand. Die nuwe 
kode wat aangebied word, word deur die lesers gerealiseer en dit impliseer dat nuwe tegnieke, temas of selfs 'n hele nuwe persepsie van tegniek en tema betekenisvol is vir sulke ontvangers. "Nieuwe literatuur gaat in op de uitdaging van de gewijzigde historische, sociale en culturele omstandigheden, maar daarbij is het perspectief van de schrijvers en het lezerspubliek waartoe zij zich richten doorslaggevend" (Fokkema \& Ibsch, 1984: 30).

Die gebruik van semiotiese terme en metodes kan beperkend wees as 'n mens streng binne die semiotiese raamwerk wil bly. Indien die konsep van kode wyd vertolk word om 'n omvattende verskeidenheid kommunikasiefaktore en strategieë in te sluit, kan dit 'n nuttige raamwerk vorm.

\subsection{Die representasie van 'n persepsie}

Nuwe strominge in die literatuur bring dikwels dramatiese verandering en vernuwing teweeg ten opsigte van onderwerp, tema, tegniek en veral ten opsigte van die beskouing van taal, die medium van die literatuur. Die begrip sosiokode kan gebruik word om die konvensies van 'n stroming te identifiseer. Die stroming kan egter nog nader omskryf word indien die klem verplaas word van die temas en tegnieke as konvensies as sodanig, na die temas en tegnieke as resultate van 'n bepaalde lewens- en wêreldbeskouing of van 'n bepaalde werklikheidsbelewing.

Shcila Friedling (1973: i) beweer dat "the representation of consciousness in twenticth-century fiction is linked to ways of perception that are both cultural and individual". Sy verduidelik:

When we speak of a cultural mode of perception, then, we mean the way of seeing and knowing that is bound to the psychological and epistemological assumptions of its leading innovators. For the artist representation is always founded on perception and is a formal or structural arrangement that reflects the world absorbed and modified by the individual who is part of it. Since perception is transformed into representation, the cognitive content of art refers not only to the ability of an art work to offer historical, actual, or possible truths, but rather to convey, in its themes and structure, the modes of individual and cultural perception. (Friedling, 1973: 2)

Die Modernisme is byvoorbeeld 'n stroming waarin bepaalde persepsies deurslaggewend is ten opsigte van sowel onderwerp as tema as tegniek. In die modernistiese tekste word daar nie gepoog om 'n objektief-bestaande werklikheid te representeer nie. Die manier waarop die werklikheid gesien en ervaar word, word weergegee of gerepresenteer sodat dit in die tekste gaan om representasies van persepsies en nie om representasie van dinge of die werklikheid nie. Daarby is die medium van die representasie, naamlik taal, vir die moderniste deel van die problematiek. 
Terwyl alle tekste van literêre strominge beskou kan word as representasies van persepsies is dit in besonder van toepassing op die Modernisme, omdat die modernistiese tekste doelbewus en eksplisiet besig is met prosesse van waarneming en interpretasie en veral met die selfrefleksiewe weergawe van hierdie aktiwiteite. Dit gaan dus nie net om die aanbieding van bepaalde waarnemings of ervarings of persepsies nie, dit gaan ook en juis om die ondersoek en ontginning van die moontlikhede (en die beperkinge) van taal waardeur hierdie "inligting" in tekste bevat kan word.

As Virginia Woolf sê "human nature changed" in 1910, gaan dit ten diepste daarom dat vir sommige mense waarneming en ervaring verander het: "On or about December 1910 human nature changed... All human relations shifted those between masters and servants, husbands and wives, parents and children. And when human relations changed there is at the same time a change in religion, conduct, politics, and literature" (Bradbury \& McFarlane, 1976: 33). D.H. Lawrence het 'n soortgelyke opmerking gemaak: "It was in 1915 the old world ended" (Bradbury \& McFarlane, 1976: 33).

Mense het sekerlik nie in 1910 of in 1915 plotseling verander of 'n gedaanteverwisseling ondergaan sodat skrywers radikaal veranderde mense om hulle gehad het as modelle vir hulle karakters nie; net so min as wat sonsondergange in die tyd van die Impressioniste en Monet radikaal anders gelyk het as daarvoor of daarna (vgl. Levin, 1966: 290). Die siening van die skrywer, sy ervaring en waarneming van mense en dinge, van die wêreld in geheel, verander. Hierdie aspek staan wel in verband met veranderinge in die werklikheid, maar gaan veel dieper. Veranderinge in die literatuur kan op geen manier bloot deur verwysing na veranderinge in die werklikheid verklaar word nie. Die literatuur kom deur mediasie tot stand en die mediasieproses staan onderworpe aan en word gekleur en ingeklee deur die waarneming en belewenis van die mediator.

Die leesproses kan op dieselfde wyse as die skryfproses beredeneer word sodat dieselfde argument ten opsigte van mediasie geld. Die leser se waarneming en ervaring van die teks word ook beïnvloed deur die persoonlike, historiese, sosiale en kulturele omstandighede waarin hy hom bevind en boweal deur die wyse waarop hierdie omstandighede in sy gees neerslag vind. Gevolglik is interpretasie uiteindelik resultaat van die leser se persepsie net so veel as resultaat van die semantiese waarde en sintaktiese patrone van die woorde in die artistieke teks. Die argument kan ook deurgetrek word na "wetenskaplike" studies oor die literatuur, want 'n bepaalde paradigma bepaal ook die epistemologie van literatuurwetenskaplike aktiwiteit. 


\section{Die Modernisme as literêre stroming}

Die Modernisme as 'n literêre stroming word deur Fokkema (1984) beskryf deur gebruik te maak van die konsep sosiokode. Deur die beskrywing van die konvensies wat die stroming bepaal in verband te bring met Friedling se siening dat representasies deur individuele en kulturele persepsies bepaal word, kan relevante gevolgtrekkings gemaak word oor die aard en wyse van representasie in die Modernisme.

Vooraf wil ek eers aandag gee aan enkele faktore wat ekstern is aan die Modernisme as literêre stroming, maar wat as omgewings- of agtergrondsfaktore deeglik met die literêre verskynsel in verband gebring kan word en help om lig te werp op die eiesoortigheid van die stroming. Uit die aard van die saak word hier volstaan met enkele kernopmerkings.

Die term Modernisme word gebruik om die radikale verandering wat aan die begin van die twintigste eeu in die kunste plaasgevind het, te beskryf. Hierdie veranderinge is in die verskillende kunsvorme merkbaar.

Die werk van Picasso word beskryf as 'n dinamiese transformasie en metamorfose en Igor Stravinsky se musiek word gekenmerk deur 'n soortgelyke gees van sistematiese deformasie. Harry Levin (1966: 275) beskryf die modernistiese gēes soos volg: "This is the will to change, in other words that metamorphic impetus, that systematic deformation, that reshaping spirit which must continually transpose itself in a dazzling sequence of newer and newest manners."

Die gees van vernuwing wat met die eeuwending oor kunstenaars vaardig geraak het, was radikaal en ekstreem in die temas wat behandel is, die tegnieke wat gebruik is, maar veral het dit gegaan om 'n breuk met die voorafgaande tradisie en die siening van sake wat dié tradisie gekenmerk het.

Dit gaan in die Modernisme oor ' $\mathrm{n}$ meer radikale benadering as om net modern te wecs. Die woord modem het in elk geval ook verskillende inhoude in verskillende tydperke. Dit gaan om 'n gans ander intellektuele benadering, 'n proses van kulturele emansipasie wat lewe as dinamiek sien (Levin, 1966: 276277).

Hoewel daar meningsverskil bestaan oor die omvang van die periode waarbinne die Modernisme geplaas word, is die bewondering vir die vernuwende krag, die intellektuele rykheid en die artistieke virtuositeit van die stroming dinge waaroor die meeste literatore en kritici saamstem. Die ingesteldheid wat as modemisties beskryf word, manifesteer in tekste in Engels, Nederlands, Duits, Frans en 
Italiaans. Die Modernisme word beskou as 'n hoofsaaklik Wes-Europese stroming, hoewel die werk van sommige Amerikaanse skrywers (William Faulkner, Saul Bellow, Bernard Malamud en Vladimir Nabokov) en Russiese skrywers (Zamjatin en Olesja) ook modernistiese eienskappe vertoon. Die Modernisme is in elk geval deur en deur internasionaal van aard: "... the essence of Modernism is its international character" (Bradbury \& McFarlane, 1976: 31) en modernistiese tekste weerspieël en bevestig "the contemporary sense of participating in a profound transition" (Bradbury \& McFarlane, 1976: 33).

Die tekste wat as modernisties beskou word, het in gemeen die ekstreme en radikale breuk met die verlede, die intellektuele gedurfdheid en die hoë premie wat op intellektualistiese en individualistiese denke val. Dit gaan vir hierdie skrywers in die laaste instansie om intellektuele mobiliteit: die modernis "voelt met zijn verstand" (Fokkema \& Ibsch, 1984: 29).

Fokkema (1984), Faulker (1977, 1986) en Levin (1966) plaas die Modernisme binne die tydperk 1910-1930, terwyl Bradbury \& McFarlane (1976) van 18901930 praat. Robert Hughes laat sy uiteensetting van die Modernisme in die beeldende kuns in 1880 begin en glo dat dit in avant-garde-bewegings tot na 1970 bly voortbestaan (Laffey, 1987: 11). Laffey (1987) sluit by Hughes se redenasie aan en beskou selfs die Postmodernisme as die laaste of 'n laat stadium van die Modernisme. Alle tekste wat modernistiese eienskappe vertoon, kan egter nie sonder meer as deel van die stroming van die Modernisme beskou word nie. Al die gesaghebbende bronne stem min of meer saam dat die stroming binne die eerste dertig jaar van die twintigste eeu geplaas kan word en dat baie vroeër of later tekste dieselfde eienskappe vertoon. So word die werk van Henry James as 'n voorstadium van die Modernisme gesien terwyl in baie ander lande en tale die modernistiese ideale tot laat in die twintigste eeu voorkom. 'n Mens kan hier dink aan die Sestigerbeweging in Afrikaans en baie Amerikaanse tekste van later in die twintigste eeu.

Skrywers wie se werk "suiwer" modernisties genoem word, sluit in T.S. Eliot, Ezra Pound, James Joyce, D.H. Lawrence, Virginia Woolf, W.B. Yeats, R.M. Rilke, V. Mayakovsky, B. Pasternak, Antonio Machado, Apollinaire, Ungaretti, Thomas Mann, Marcel Proust, Franz Kafka en Italo Svevo. Daar moet egter dadelik bygevoeg word dat baie ander skrywers ook moderniste genoem word hoewel hulle werk nie altyd ewe tipies van die Modernisme as stroming is nie (byvoorbeeld E.M. Forster, Joseph Conrad, André Gide en vele ander).

Net soos die grense van 'n stroming histories moeilik vasgepen kan word, is die skeiding of onderskeiding tussen aanverwante en kontemporêre strominge ook 
moeilik aantoonbaar. Daar is raakpunte of ooreenkomste tussen Modernisme en Ekspressionalisme, Futurisme, Kubisme, Dadaïsme, Konstruksionisme, Surrealisme, abstrakte Ekspressionisme, Minimalisme, Imagisme (waarin sekere modernistiese eienskappe in ekstreme en gekonsentreerde vorm voorkom) en selfs die Romantiek (vgl. Bradbury \& McFarlane, 1976: 44-47; Laffey, 1987:10). Dit is egter belangrik dat die Modernisme direk teenoor die Simbolisme en die Realisme te staan kom. Waar die simbolistiese skrywer die kunswerk as 'n kristal, 'n selfgenoegsame en onaantasbare entiteit beskou, verwerp die modernis die gedagte van 'n superieure, onveranderlike idee. Waar die simbolis hom van die lewe afkeer, wil die modernis die wêreld aanspreek, hy wil reis in plaas van mediteer, hy wil die vensters oopgooi en die mufheid van die toe vertrek agterlaat (Fokkema, 1984: 20). Die titel van E.M. Forster se roman $A$ room with a view benoem nie net die roman of die gesindheid van sekere karakters in die roman nie, maar beskryf inderdaad die gesindheid waarmee die lewe en die kuns deur die modernis benader word.

Waar die Realisme familiebande en nasionalistiese emosies verheerlik, stel die modernistiese skrywers die vertrek, die afreis voorop. Hulle wil onverbonde wees, losgemaak van familie en volk en land of staat. Hulle wil ontvoog wees: hulle is onttrokke. Soos reeds gestel, is hulle gerig op die internasionale, die uitheemse en vreemde. Menslikheid setel vir hulle in onafhanklikheid van 'n bepaalde en bepērkende omgewing en sosiale agtergrond. James Joyce se $A$ portrait of the artist as a young man is byvoorbeeld die verhaal van so 'n ontvoogding van 'n jong man. Die outobiografiese inslag van die roman onderstreep die gedagte nog sterker.

Vir die modernis gaan dit ten diepste om 'n radikaal ander manier van kyk na die werklikheid. Gertrude Stein sê van Picasso: “... the reality of the twentieth century is not the reality of the nineteenth century, not at all, and Picasso was the only one in painting who felt it, the only one. More and more the struggle to express it intensified..." (Friedling, 1973: 7).

Hierin lê die sleutel tot die manier waarop die modernis die werklikheid benader. Daar is in die houding sowel betrokkenheid as onttrokkenheid. Hulle wil vry wees van beperkende konvensies en vaste skemas om die werklikheid as fenomeen direk en oop en vry te ervaar.

Daarom woon Joyce in Zurich en Parys terwyl hy skryf oor Dublin, oor Iers wees, oor religie en spesifiek oor Katolisisme. Vanaf 'n afstand is hy onttrokke, ontwortel en bevry - hy kan nooit sy Ierse herkoms, sy kulturele en religieuse tradisies agterlaat nie, maar voordat hy daaroor skryf, moet hy daarvan bevry 
wees. Harry Levin beskryf hierdie verhouding van gelyktydige betrokkenheid en onttrokkenheid by Joyce soos volg:

The first consideration with an Irishman, is nationality. Joyce, like Stephen, was "all too Irish" - all the more Irish because he was a "wildgoose", because he resided mainly in foreign countries... From first to last, his underlying impulses were those of his racial endowment: humour, imagination, eloquence, belligerence... Escaping from the treadmill of Dublin, Joyce spent the rest of his life brooding upon it and writing about it. (Joyce, 1983: 12)

Die negentiende-eeuse rasionalistiese en idealistiese epistemologie wat dualisties en dogmaties was en wat denke en opvattinge en waarneming vooraf wil rig en bepaal, is vir die modernistiese gees onaanvaarbaar. Saam met die ontwikkeling van empirisisme in die wetenskap, wat 'n dogmatiese konseptuele wêreldbeeld afwys en 'n metode van relatiwiteit en ontwikkeling voorstaan, wil die Modernisme ook met 'n nuwe paradigma werk, waarin 'n nuwe manier van dink figureer. Relatiwiteit, verandering, ontwikkeling word waargeneem en weergegee. Die sielkundige werklikheid word as 'n temporele en eksistensiële proses ervaar en nie as 'n vaste gegewenheid nie (Friedling, 1973: 8-22). Die weergawe van hierdie soort belewenis is dan ook onderworpe aan dieselfde relatiwiteit en tydelikheid en veranderlikheid.

In die modernistiese literatuur, soos in die sielkunde en filosofie, gaan dit om 'n ontwikkelende bewussyn en die representasie van die resultaat van vrye omgang met en waarneming van die werklikheid. "Of particular importance to representation in fiction are ideas about the nature of consciousness, perspective, the relationship between subject and object, truth, chance and choice - ideas that reflect shifting assumptions about the categories of substance, causality, time and space" (Friedling, 1973: 34).

Die eerste Wêreldoorlog sluit die era van negentiende-eeuse denke finaal af (vgl. Virginia Woolf se uitspraak oor 1910 en D.H. Lawrence s'n oor 1915). Tog het hierdie oorlog van ongekende wreedheid en ontbering min uitwerking op die Modernisme behalwe miskien in die geval van Thomas Mann. Dit lyk asof die aflê van die positivisme van Hippolyte Taine met die bekendwording van Dilthey se Die Entstehung der Hermeneutiek (1900) en Freud se Traumdeutung (1900) groter invloed op modernistiese skrywers het as die uiterlike gebeurtenis van die oorlog. Hierby sluit dit logies aan dat dit in die Modernisme gaan om die presentasie van die innerlike intellektuele verwerking en oorweging van uiterlike gebeure en nie om die gebeure as sodanig nie.

In die belangrikste uitsprake oor die Modernisme gaan dit telkens om die nuwe visie en die stryd om daaraan uitdrukking te gee. Friedling (1973: 22) praat van 
'n individuele en kulturele "mental set - a new way of perceiving reality and of expressing it". Dit gaan dus om 'n hiperindividualistiese belewenis, binne 'n bepaalde kulturele atmosfeer en die strewe om in 'n bepaalde medium daaraan uitdrukking te gee: "Not only did the modernist artist see himself confronted by the infinite complexity of reality, he also saw that his medium itself might be part of the problem" (Faulkner, 1977: 15). Hierdie aspek van die Modernisme is deur Stephen Spender in sy gesaghebbende werk The struggle of the modern (1953) soos volg beskryf: "Modern art is that in which the artist reflects awareness of an unprecedented modern situation in form and idiom ... the principle of reality in our time is peculiarly difficult to grasp, and ... 'realism' is not an adequate approach to it" (Faulkner, 1966: 15).

In a modernistiese teks word daar nie dinge gerepresenteer nie. Representasie as sodanig is vir die modernis verdag. Die verhoudinge tussen sake en woorde is gans relatief, die signifié is ook veel minder belangrik as die signifiant. Dit wat aangebied word, bestaan nie vooraf nie, dit kom in die teks tot stand. Waarmee 'n mens waarskynlik in 'n modernistiese teks te make het is die presentasie van 'n spesificke individueel en kultureel bepaalde persepsie van die wêreld waar die representasiemedium (taal in geval van die literatuur) net so problematies en relatief is soos die wêreld en die siening van die wêreld. In die Modernisme vind ons weerspieël die resultaat van die verskuiwing van 'n transendentale wêreldbeeld na 'n fenomenologiese wêreldbeskouing wat altyd aan 'n bepaalde visie, perspektief of siening gekoppel is. Daarom kan Levin (Joyce, 1983: 9) van die modernistiese werk van James Joyce sê: "There have been other demonstrations, but none so pertinent, of how an original mode of expression can help us to grasp a new phase of experience". Hierdie stelling word ondersteun deur 'n uitspraak van Linda Brodkey (1987: 399), wat, hoewel sy heftig te velde trek teen die elitistiese en individualistiese aard van die Modernisme, tog dieselfde essensie in die modernistiese teks as 'n taalverskynsel raaksien: "Modernism is not the way things are, but the way things appear to us because its metaphors and vocabulary prevail, hence, constituting an ideology of experience."

\section{Die sosiokode van die Modernisme}

Die Modernisme is 'n komplekse verskynsel waaroor daar, waarskynlik juis as gevolg van die kompleksiteit daarvan, al biblioteke vol boeke geskryf is. $\mathrm{Om}$ iets nuuts oor die Modernisme te sê, kan slegs vanuit 'n nuwe paradigma gedoen word deur byvoorbeeld 'n ideologies-kritiese of dekonstruktiewe lesing van 'n modernistiese teks te maak. Dit is inderdaad ook al gedoen (vgl. Laffey, 1987; Brodkey, 1987). 
In hierdie artikel word gepoog om vas te stel hoe die sosiokode van die Modernisme daar sou uitsien. Dit word gedoen aan die hand van aspekte van die sosiokode wat Fokkema (1984; Fokkema \& Ibsch, 1984) in die stroming aangetoon het. Binne hierdie raamwerk word resultate uit ander studies oor die Modernisme geïnkorporeer in 'n poging om die representasie-opvatting onderliggend aan die Modernisme as stroming te probeer beskryf. In die hantering van standaardbronne word die verskille in benadering van ondersoekers nie uitvoerig verreken nie: dit gaan hier immers nie om die representasie-opvatting van die ondersoeker nie, maar om die representasieopvatting van die modernis te probeer vind.

Om die Modernisme in 'n beperkte studie te behandel, is 'n riskante onderneming, want soos Harry Levin (1966: 184) dit stel: "Yet at this distance we can perceive, with increasing clarity, that the modernistic movement comprises one of the most remarkable constellations of genius in the history of the West."

Weens die beperktheid van 'n artikel soos hierdie, kan 'n mens hoogstens die opvallendste eienskappe van die stroming aantoon en enkele totaal ontoereikende voorbeelde gee omdat daar soveel skrywers en soveel tekste is en daar net so veel (waarskynlik selfs veel meer) afwykings en variasies as ooreenkomste bespreek kan word.

\subsection{Selfbewussyn en persepsie}

Ek neem as vertrekpunt die reeds beredeneerde stellings dat dit in die Modernisme nie gaan om 'n representasie van die werklikheid nie, maar om die presentasie van 'n persepsie van die wêreld en die mens; dat die persepsies van die werklikheid individueel sowel as kultureel bepaal is en dat die problematiese aard van die proses om aan die persepsie uitdrukking te gee, dit wil sê die taalmatige weergawe, sentraal staan.

Hierdie stelling kan aan die meeste modernistiese tekste geillustreer word. Die bewustheid van ' $n$ individualistiese siening of ervaring of waarneming bepaal sowel die dinge waaroor geskryf word as die manier waarop geskryf word. Die visie of persepsie van die karakter word sterk vooropgestel, maar die uiteindelike samehang (of juis die gebrek daaraan) is die resultaat van die skrywer se persepsie.

Perspektief, die sogenaamde point of view, is byvoorbeeld die aspek van die literêre teks wat Henry James (wat vóór die hoogty van die Modernisme leef en skryf) die sterkste beklemtoon. Hy sien 'n bepaalde perspektief as die enkele belangrikste samebindende faktor in die verhaal en noem hierdie fokuspunt die 
"centre" van 'n verhaal. Die handeling en betekenis van die verhaal setel vir hom in die "embracing consciousness" van 'n (hoof-) karakter "whose psychological sensitivity and drama would clearly evoke controlling interest" (Miller, 1972: 10).

Hier vind 'n mens reeds die weergawe van belewenis, van visie, en nie 'n objektief kenbare of kontroleerbare en algemene werklikheid nie.

Thomas Mann se werk verskil van die literatuur van sy voorgangers ook juis vanweë 'n verhoogde of geïntensiveerde bewussyn en 'n ironiese bevraagtekening van situasies: “' 'aestheticism' is for him always a matter of heightened consciousness" (Stern, 1976: 426). In Der Tod in Venedig word die kontras tussen die lewe in natuurlike vorm en die artistieke ingesteldheid in die karakter van Gustav von Aschenbach aan die orde gestel. Hierdie selfde konflik kom ook in Felix Krull en Königliche Hoheit voor en uiteindelik triomfeer kuns oor werklikheid. Stern (1976: 426) beskou hierdie oorwinning van kuns as "so complete that it makes life itself into an aesthetic phenomenon - but it does so in a world that offers no serious resistance to being moulded by the artistic disposition for its aesthetic ends".

Dit gaan dus nie meer net om die persepsie van die karakter nie, maar om daardie perscpsie wat die skeppende aktiwiteit bepaal. Die vormgewende en aardbepalende faktor is dus die artistieke persepsie, wat die realistiese konvensie ondermyn en 'n nuwe bewussyn daarstel waar hierdie bewussyn die grense van die wêreld van gemeenskaplike en alledaagse betekenis oorskry.

Die baie bekende passasie uit Virginia Woolf se essay "Modern fiction" (1919) beklemtoon ook die individuele waarneming van 'n spesifieke bewussyn. Sy beskryf hoe die menslike gees miljarde indrukke van uiteenlopende aard registreer en hoe hierdie proses voortdurend plaasvind. "Life is not a series of gig lamps symmetrically arranged; life is a luminous halo, a semi-transparent envelope surrounding us from the beginning of consciousness to the end... Let us record the atoms as they fall upon the mind in the order in which they fall, let us trace the pattern, however disconnected and incoherent in appearance, which each sight or incident scores upon the consciousness" (Woolf, 1972: 8889).

Die spel met perspektief wat in die Modernisme doelbewus beofen word, het in die loop van die twintigste eeu tot een van die mees verfynde aspekte van die romanvorm ontwikkel. Uitgebreide teoretiese navorsing en besinning is onderneem om die kompleksiteite van fokus en fokuswisselinge te beskryf: studies oor point of view, perspektief of fokalisasie en vertelling is baie volop, 
juis aangesien die modernistiese roman as prototipe tot menigvuldige artistieke eksperimente met fokus aanleiding gegee het.

Die invloed van Nietzsche op die kunstenaars van die vroeë twintigste eeu is baie sterk. Die gedagtes in The birth of tragedy (1871) kan oral teruggevind word in die literatuur. Veral die dialektiese skema wat hy uitwerk, word ge-eggo en vergestalt in die modernistiese tekste. Hierdie dialektiek voorveronderstel tweeledigheid as die basis van die lewe, die Janus-gesig as die essensiële metafoor van menslike bestaan: "Whatever exists is both just and unjust and equally justified in both" (Nietzsche soos aangehaal in Kuna, 1976: 444).

Die bewustheid van tweeledigheid (wat deur perspektiefwisseling bevestig word) blyk uit baie modernistiese werke. In Heart of darkness van Joseph Conrad staan Kurz as idealistiese Europeër wat die duisternis van Afrika aangryp en met die boosheid heul teenoor die winsbejag en eksploitasie van die Eldorado Exploring Expedition. In "Metamorphosis" van Franz Kafka word twee aangesigte van die lewe getoon: Gregor se "gestadigde" dood in die vorm van 'n reusagtige miskruier, simboliseer die menslike strewe om die lewe te transendeer, terwyl sy suster se jeug en toenemende lewenskragtigheid die aardse, maar energieke en byna dierlike sy van die lewe simboliseer. Hierdie dualistiese aard van die bestaan word voorgehou sonder om een faset as positief of beter as die ander voor te stel. Die "gelykenis" stel die paradoksale voorop en maak geen morele appèl nie.

Paradoks en ironie vorm skering en inslag van die modernistiese literatuur. Dit sluit direk aan by dié uitspraak van Nietzsche (Kuna, 1976: 452): "There are no such things as facts, only interpretations". Kuna (1976: 452) sê dan ook: "In modern fiction Nietzsche's concept of innumerable intellectual perspectives appears in the form of innumerable existential possibilities".

Wanneer Mrs. Moore in E.M. Forster se $\boldsymbol{A}$ passage to India uit Indië vertrek sien sy in "the twilight of the double vision" sowel die verskrikking van die heelal as die nietigheid daarvan sodat "we can neither ignore nor respect Infinity".

\section{Voorlopigheid as voorveronderstelling}

Die belangrikste konvensie in die Modernisme ten opsigte van die komposisie van die tekste is die hipotetiese aard daarvan, waar hierdie hipotetiese aard 'n deurlopende onsekerheid en voorwaardelikheid impliseer. Die voorlopigheid van die teks het te make met die verhouding tussen die teks en die outeur. Die outeur is nie die sentrum waarom betekenis sentreer nie, die teks is nie voltooid, volledig of afgehandel nie. Nòg die self, nòg die kunswerk wat die self 
uitbeeld, is afgerond of stabiel. Die menslike natuur word beskou as "in a state of continuous becoming" (Singhal, 1987: 15).

Fokkema (1984: 15) verwys na die onvolledige, onklaar aard van verskeie modernistiese tekste. Svevo skryf Confessions of Zeno (1923), maar dit word later aangevul deur Further confessions of Zeno. Die gebrek aan fmaliteit in 'n teks bring mee dat die slot relatief is. Die teks kan voortgesit word. Hierdie gedagte sluit aan by die gewildheid van die dagboekvorm by die modernistiese skrywers (vgl. $A$ portrait of the artist as a young man van James Joyce en $\mathrm{Het}$ land van herkomst van Du Perron).

Die romans bevat gewoonlik nie 'n duidelike en beslis geen realistiese storie nie. Die verhalende gegewens word dikwels in mitiese gedaante aangebied. Joyce skryf oor mense in Dublin, maar deur Stephen Dedalus en Leopold Bloom met die mitiese figure van Telemachus en Ulysses uit die Odusseia in verband te bring, word die besondere en die algemene in die betekenis van hulle lewe en handelinge aan die orde gestel.

Die klem op die onmiddellikheid van ervaring sluit aan by die onvolledigheid en voorlopigheid van die teks. In die onmiddellike ervaring lê outentisiteit en hierdie outentisiteit moet ook in die teks, die (re-)presentasie van die ervaring, na vore kom. Afgerondheid of volledigheid of sluitende finale betekenis is dus vir dié skrywers nie moontlik nie (Singhal, 1987: 15).

Terselfdertyd is die modernis hiperbewus daarvan dat hy niks seker kan weet van of die wêreld of van homself nie. Die werklikheid is voortdurend aan die beweeg en verander en die mens ook. Gevolglik moet die modernis bewus wees daarvan dat hy streef na integrasie en outentisiteit, maar dat hy dit nooit kan bereik of bewerkstellig nie - nie in die werklikheid of in die kuns nie. Integrasie is ook nic wenslik nie, want dit sou stilstand en stagnasie beteken. Vandaar Virginia Woolf se uitspraak dat die lewe in los atome wat op die menslike bewussyn val, ervaar word en in die kuns gepresenteer moet word.

Die ervaring van die ongevormde, die chaotiese en onbegryplike lei tot 'n behoefte daaraan om vorm en samehang te vind of te gee, maar die onvermoë daartoe en die onmoontlikheid daarvan is onontkombaar: "But in order to make you understand, to give you my life, I must tell a story - and there are so many and so many..." (Bernard in The waves van Virginia Woolf.)

'n Bepaalde interpretasie van die werklikheid bepaal die persepsies wat in die teks gepresenteer word en dit is ' $n$ interpretasie wat die onbegryplike, voorlopige en vloeibare aard van die ervaring van die werklikheid vooropstel. 


\subsection{Epistemologiese twyfel}

In samehang met die voorafgaande stellings is dit duidelik dat die verhouding tussen die teks en die gerepresenteerde wêreld vir die modernis onderworpe is aan 'n diepgaande epistemologiese twyfel: die modernis kan nie en wil nic voorgee dat die teks inderdaad daarin sou kon slaag om die wêreld, 'n wêreld te beskryf nie. Dit wat aangebied word, is hoogstens 'n uitreik na 'n moontlike waarheid.

Waarheid of selfs geldigheid staan vir hulle op bewegende en wankelende fondamente. Fokkema (Fokkema \& Ibsch, 1984: 155 e.v.) sien Gide se bespiegelings oor en eksperimente met ongemotiveerde handeling as 'n illustrasie van die voorlopigheid van die teks en die omverwerping van maatstawwe van waarheid. In Les Caves du Vatican word die aard en uitwerking van gerugte aan die orde gestel deur 'n verteller wat "aarsel" om gerugte oor te dra en wat sy sogenaamde inligting met 'n voetnoot "bewys". Indien die leser die gerug aanvaar (en die leser sal waarskynlik, want dit gaan om die bewering dat die pous ontvoer is soos wat daar dikwels in die geskiedenis beweer is dat die pous ontvoer is), kan hy die verdere onwaarskynlikhede in die roman nie verwerp nie. Daar is dan geen kriterium meer om gebeurtenisse vir "waarheid" te toets nie. Dit skep die geleentheid om die intellektuele moontlikhede van die mens te verken - buite die beperkinge van 'n realisties-vasgepende waarheid.

Hierdie skeptisisme is tipies van die vroeë twintigste eeu op haas alle lewensterreine. Politieke ontvoogding van onderdrukte groepe, die stryd om sosiale bevryding (byvoorbeeld die feministiese vryheidstrewe van die suffragettes), die bevraagtekening van dinge wat voorheen onbetwis aanvaar is, is in die meeste Europese lande aan die orde van die dag. Gesag, patriotiese en religieuse opvattings - veral die Christelike godsdiens - word as aanvegbaar beskou. Die sielkunde stel die mens nie meer voor as rasionele of religieuse wese nie, maar as onderworpe aan instinkte en die donker onkenbare drange van die onbewuste.

As gevolg van die bewustheid en ervaring van groter kompleksiteit, as gevolg van die bewustheid van 'n gebrek aan samehang, is modernistiese tekste nie maklik of eenlynig nie en die samehang daarin is nooit opvallend of oppervlakkig bepaalbaar nie.

Die gebrek aan samehang in die modernistiese teks gaan veel dieper as die weerspieëling van 'n onsamehangende werklikheid. Die gaan om die onvaste, twyfelagtige aard van die waarneming en ervaring van die mens. Die problematiese aard van samehang in die werklikheid, in belewenis of in die kuns, is vir die modernis die essensie van welke belewenis ook al - die 
Janusgesig is altyd daar. Dit werk so sterk deur in hulle kunsbeoefening dat hulle die tradisionele genres verwerp - die bestaande vorme, veral romanvorme wat in die realistiese tradisie geyk geraak het, is vir hulle radikaal ontoereikend. Virginia Woolf (1972: 86-91) beskryf die modernistiese romans dan ook as impressionistiese verwerpings van "the well-made novel".

James Joyce se werke is in baie opsigte sonder voorgangers (Levin, 1966: 288). Die oorheersende faktor wat die werk bepaal, is die "metamorphic impetus": Ulysses is gestruktureer rondom die transmutasie van gewone inwoners van Dublin tot mitiese argetipes uit die Odusseia. Die aanklag van onsamehangendheid is dus nie geregverdig nie - dit gaan in die artistieke modernistiese teks om 'n artistieke struktuur of artistieke samehang wat nie die logika waarna in die werklikheid gestreef word, eggo of weerspieël nie. Vir die modernis is die onvolkomenheid van die strewe na orde en sin, die vlugtigheid van insig, die mislukking en inkonsekwensic van bestaande menslike stelsels in die werklikheid, opvallender en geldiger as die patroonmatighede of voorspelbaarheid of logika.

Die samehang kom nie uit die werklikheid nie: die samehang is 'n tekstuele of artisticke strategie wat eerder vrae vra as antwoorde bied of ideale voorhou. Joyce se werke en Proust se soeke na verlore tyd illustreer hierdie eienskap.

In Ulysses (Joyce, 1947: 696-698) word die verhaal onder meer vertel deur vrae te vra en bespiegelende antwoorde te gee. Die antwoorde op die vrae gee geen samehangende verklaring nie, en dit is duidelik dat dit juis gaan om die onmoontlikheid van samehangende antwoord. "What retribution, if any? Assassination, never, as two wrongs did not make one right. Duel by combat, no. Divorce, not now. Exposure by mechanical artifice ... not yet..." En uiteindelik bly die vraag onbeantwoord.

Die epistemologiese onsekerheid hang nou saam met die problematiese aard van die konsep tyd vir die modernis. "Why can't you beat time?" vra die Gracehoppcr vir die Ondt in Joyce se Finnegan's wake (Joyce, 1983: 528).

En dit is presies wat Proust probeer doen in A la recherche: om die beperkings van tyd te oorskry. Die hoofkarakter ervaar sy lewe as 'n netwerk van verwikkelde herinneringe en belewenisse sodat Genette die tegniek as omnitemporality beskryf. Die antisipasies van die kind wat deur die volwassene in herinnering geroep word, staan meestal in skerp kontras tot die werklikheid wat gerealiseer het - 'n "unhoped-for paradise" waarna uitgesien is en waaroor met groot intensiteit gedroom is, word ervaar as "a prosaic and totally charmless reality". Die spel met tyd stel veelvuldige moontlikhede aan die orde: 
"... this complex system of frustrated expectations, disappointed suspicions, surprises, looked forward to and finally all the more surprising in being looked forward to and occurring nonetheless..." (Genette, 1980: 77).

Die omnitemporality, die gelyktydige en komplekse bewustheid van verlede, hede en toekoms, die toekoms soos in die verlede en die verlede soos in die toekoms gesien, is die kern van die eiesoortigheid van Proust se roman. Wat het gebeur? Hoe is dit vooraf gesien, hoe is dit beleef en hoe word dit in retrospeksie gesien? Wat is die betekenis daarvan? Is daar betekenis? Tyd gly onder die waarnemer uit, tyd is nie vas te vang nie - ervaring en interpretasie staan onvermydelik gerysmier deur tyd.

Volgens Levin (1966: 187) was dit vir Proust 'n lewenstaak om tyd te probeer transendeer, om die beperkinge van tyd te oorskry in "the attempt of an ageing dilettante to make up for lost time by recapturing the past, repudiating its ephemeral concerns and crystallizing its highest moments through an appeal to the timelessness of art".

Die modernis vind 'n outentieke en geintensiveerde bestaan in die kuns, in die outonome strukture van die artistieke werk, wat uiteindelik los van skrywer en geskiedenis, 'n momentele ervaring is.

Die modernis sien die artistieke aktiwiteit as een manier, dié manier om die onvolkomenheid van die werklikheid te transendeer. Die belangrikheid van die artistieke werk en die kreatiewe handeling vir die modernistiese kunstenaar word deur Bradbury \& McFarlane (1976: 51) soos volg saamgevat: "It illuminates, too, that passion in Modernism to see the universe as contingent, poverty-stricken, denuded until it has been reimagined, its local virilities apprehended through the planes and conjunctions available to the fictionalizing mind" (Ek kursiveer - H. du P.).

Die ontkenning van die onafhanklike en onveranderlike bestaan van oorspronklike gegewens, die verwerping van die moontlikheid van 'n stabiele wêreld met vaste betekenis, maak dit onmoontlik vir die modernistiese teks om te representeer. Die modernistiese roman kan immers nie iets representeer as hy wil sê dat hy nie weet wat is nie. En logies volg hieruit dat hy homself ook nie kan aanbied as iets vas en rigied en as draer van regulerende of gereguleerde betekenis nie. Die modernistiese roman vra dus implisiet en eksplisiet voortdurend na sy eie syn. Hierdie romans is nie in diens van 'n gerepresenteerde werklikheid nie, maar is aan hulle eie ontologie toegewy. Daaroin presenteer so 'n teks homself vir wat hy is en nie vir wat hy representeer nie. 


\subsection{Metalinguistiese skeptisisme}

'n Baie belangrike modernistiese konvensie is die voorliefde om die kodes wat in die literatuur gebruik word, te bespreek, uit te pluis en te bevraagteken. Dit gebeur binne die romans, maar ook daarbuite soos blyk uit die feit dat van die belangrikste bronne van inligting oor die modernisme die essays, dagboeke en briewe van modernistiese skrywers is.

Volgens Fokkema (1984: 8 en 17) word op al vyf die sentrale kodes van literêre kommunikasie, wat volgens hom die sosiokode uitmaak, deur die modernistiese skrywers selfrefleksiewe kommentaar gelewer. Dit beteken dat taal as sodanig as linguistiese kode, die literatuur self as 'n literêre kode, die vorm van die werke as 'n generiese kode, die periodekode van die modernistiese eiesoortigheid en die idiolek van elke skrywer as kode dikwels, implisiet of eksplisiet, tot onderwerp van die werk geneem word, of uitvoerig in 'n teoretiese geskrif of essay bespreek word.

Sulke kommentaar vind 'n mens byvoorbeeld in T.S. Eliot se essays, in Virginia Woolf se briewe en dagboeke en in die korrespondensie tussen Du Perron en Ter Braak. Die roman of die romankuns word egter ook binne die romans aan die orde gestel. André Gide se roman Les Faux-Monnayeurs is 'n roman wat juis handel oor die skryf van 'n roman, hierdie spesifieke roman. In Finnegans wake word die aard van die teks as 'n moontlike wêreld soos volg beskryf: "What has gone? How it ends? Begin to forget it. It will remember itself from every sides, with all gestures, in each our word. Today's truth, tomorrow's trend. Forget, remember!" (Joyce, 1983).

Soos reeds uiteengesit, is die modernistiese teks selfgerig en dit is hierdie selfgerigtheid wat manifesteer in die metalinguistiese bewussyn van eie aard en vermoë. Wat egter baie duidelik is, is dat hierdie selfbewussyn deur dieselfde skeptisisme cn twyfel deursuur is as die verhouding met die werklikheid en die geskiedenis. Die invloed van Nietzsche se Sprachskepsis wat by Bergson se taalfilosofie aansluit, is baie duidelik in die Modernisme. Alles wat gesê kan word, is ook maar voorwaardelik: "... die Forderung einer adäquaten Ausdrucksweise ist unsinnig" (Fokkema, 1984: 18).

Hugh Kenner (1987: 99) beskou die intense bewustheid van taal en die siening dat taal die mees onontginde modus van menslike gedrag is, as die belangrikste eienskap en bydrae van die Modernisme. Vir die modernis vereis en verdien die taal toewyding en aandag, want dit kan net so maklik verskuil en verberg as wat dit betekenis kan oordra. Die Russiese Formaliste sien die funksie van literariteit, vervreemding en kunsgrepe as die de-outomatisering van die leser ten opsigte van dic werklikheid en die teks. Deur middel van die literatuur word 
'n verskerpte aandag vir die werklikheid, vir die objek agter die teks gevra: "to make the stone stonier" en dit is die teks, die literatuur wat dit bewerkstellig. Die modernis wil egter uitsluitend verskerpte aandag vir die teks self vra. Vir die modernis verminder die referensiële vermoë van taal wanneer die teks selfrefleksief raak.

Die epistemologiese twyfel oor wat is, beïnvloed duidelik die taal van die Modernisme. David Lodge (1976) ondersoek die taal van die modernistiese tekste en hy kom tot die gevolgtrekking dat omdat die modernistiese teks voortdurend met pluraliteit en onbepaalbaarheid werk, die metafoor die natuurlike vorm van uitdrukking vir die modernistiese persepsie is. Dit blyk duidelik in Joyce se Ulysses en Virginia Woolf se To the lighthouse.

Daar word 'n spel met taal gespeel, taal word ontgin en uitgebuit, maar ook gerelativeer en byna ontkrag. Die resultaat is egter nie dat taal werklik leeg word nie, maar dat die representatiewe vermoë van taal ontkrag word om metaforiese, konnotatiewe en assosiatiewe waarde te verkry.

In Finnegans wake ontwikkel en gebruik Joyce "an artificial language of innuendo and mockery" wat hy "scrabbledegook" noem en wat uiters ontoeganklik is: "What if she be in flags or flitters, reekierags or sundyechosies, with a mint of mines or beggar a pinnyweight. Arrah, sure, we all love little Anny Ruiny, or, we mean to say, lovelittle Anna Rayiny, when unda her brella mid piddle med puddle, she ninnygoes nannygoes nancing by" (Joyce, 1983: 496).

Harry Levin (1977: 17) sê van hierdie verskynsel: "Pessimists may interpret this ambiguous phenomenon as the annihilation of all meaning. A chain reaction set off by the destruction of the atom. Optimists will emphasis the creation of matter ex nihila, and trust in the Word to create another World".

Hugh Kenner (1987: 105) sê onomwonde: "We're not allowed to forget how it's words, words, words we're coping with".

Die beskouinge oor taal en die implementering daarvan in tekste is terselfdertyd illustrasie van die modernistiese skrywer se ingesteldheid op sy eie idiolek en die ontwikkeling daarvan. Die objektiewe wêreld is nie primêr nie, maar die bewussyn van die skrywer en dic nuwe woorde en vorme waarin hierdie nuwe persepsies van die modernistiese bewussyn gepresenteer word. Sonder twyfel kan gesê word dat hierdie woorde nie refereer nie en dat hulle ook nie objekte representeer nie. Dit gaan uiteindelik om 'n presentasie van die problematiek van woorde. 
Dié romans konsentreer so sterk op die werking van taal en taalstrukture (wat die negativering van die tradisionele roman as taalstruktuur insluit) dat gepraat kan word van "the reduction of fiction to its ontologically reflexive surfaces" (Levin, 1977: 89). Levin (1977: 89 e.v.) toon aan dat hierdie reduksie plaasvind ten opsigte van beelding, van klank, van semantiek en van die verhalende struktuur. Die doel van die reduksie is om die geykte strategieë van die tradisionele roman te ontmasker, te elimineer, sodat die roman as roman, as taalteks raakgesien kan word: "It lets the conventionally suppressed novelhood of the novel come forward to the surface". Dit bewerkstellig 'n "expansion of consciousness" - die taal en die woorde beperk nie en pen nie vas nie, dit skep nuwe ruimtes en moontlikhede. Deur die moontlikhede en die noodwendige beperkinge van die roman aan die orde te stel, word van die leser intelligente samewerking vereis, die leser moet aan die komplekse proses deel hê, hy moet aktief meewerk om die proses te laat realiseer.

Die selfrefleksiewe aard van die modernistiese roman lei desnieteenstaande nie tot 'n gesprek in 'n vakuum nie. Die betekenis van die romans lê nie daarin dat 'n bestaande betekenis in die werklikheid gepresenteer word nie, maar dat 'n nuwe betekenis en moontlike betekenisse in taal tot stand gebring word en hierdie betekenisse het wel betrekking op die kondisie van die mens in die werklikheid. "By dwelling upon that interrupted nuance, that unconsummated moment, that unrealized possibility, Joyce renews our apprehension of reality, strengthens our sympathy with our fellow creatures, and leaves us in awe before the mystery of created things" (Levin, 1977: 19).

\subsection{Vryheid van die leser}

Uit die voorafgaande beskrywing van die konvensies van die Modernisme, vloei noodwendig voort dat hierdie skrywers en hulle tekste die leser radikaal anders benader as wat in die voorafgaande romantradisie die geval was. Indien die teks voorlopig is, indien die teks die werklikheid verwerp vir 'n hipotetiese werklikheid, indien dic metaforiese aard van taal uitgebuit word om die grense van die bewussyn uit te stoot, kan daar tog nie van die leser verwag word om enkelvoudige en strak lesings te maak nie. Dit is trouens onmoontlik in die atmosfeer van relatiwiteit en skeptisisme waarop die Modernisme floreer.

Modernistiese romans is intellcktucel en individualisties en ingewikkeld. Dit bring mec dat die lees van sulke tekste veeleisend is. Kenner (1987: 107) beweer dat die Modernisme teruggaan op 'n tradisie van veel vroeër wat betref die eise wat aan die leser gestel word. Erudisie was 'n voorvereiste en kon vooraf veronderstel word in die Middeleeue en Renaissance. In die agtiende en negentiende eeu het mense al meer begin lees en het boeke al hoe meer en makliker beskikbaar geraak. Dit het gelei tot die era van die "Maklike Boek". 
Dante het geweet dat diegene wat sy werk lees, 'n bepaalde ontwikkeling en veral ' $n$ bepaalde leeservaring sou hê omdat almal wat binne sy breë kultuurverband ontwikkel genoeg was om te kon lees, min of meer dieselfde werke sou gelees het en oor 'n $\min$ of meer ooreenstemmende verwysingsraamwerk sou beskik. Hy kon ook 'n bepaalde ingesteldheid teenoor lees as akademiese en intellektuele aktiwiteit veronderstel en daarom kon hy skryf met die idee dat "he was bequeathing us a book we'd not wear out in a lifetime" (Kenner, 1987: 108).

Die modernistiese strategie bestaan daarin dat bestaande konvensies (wat dan die konvensies van die "Maklike Boek" insluit) verwerp word, dat uit hede, verlede en toekoms dit wat assosiatief versoenbaar is, geneem word, dat allerlei uiteenlopende dinge bymekaar gevoeg word in 'n ongewone vorm. Die transformasie van gewone en ongewone dinge tot "something rich and strange" vereis geskoolde en denkende lesers.

Die spel wat met die leser gespeel word, is 'n intellektuele spel - net so veeleisend ten opsigte van kennis en aanvoeling en aanpassing, net so ontstellend ten opsigte van omverwerping van geykte en gemaklike idees, net so verrykend ten opsigte van die ekspansie van die bewussyn vir die leser as vir die skrywer. Die bydrae van die leser kry van die modernistiese skrywer self sanksie: Gide laat 'n skoon bladsy agter in Paludes oop waarop die leser sy mening kan lug en die roman kan aanvul volgens sy smaak.

Lesers het inderdaad die nuwe toonaard van die Modernisme aangevoel. Volgens Fokkema (1984: 14) realiseer die kode eers wanneer die lesers dit raaksien en dan kan die stroming as 'n historiese feit geïdentifiseer word. Hy gee bewyse van vroeë lesings van Proust, Joyce, Mann en andere se werk om aan te toon dat die eiesoortigheid van hierdie werk en die ooreenkomste in benadering deur lesers raakgesien is. Die breuk met die representeerbare werklikheid en die opgaan in metaforiek, maak van die modernistiese tekste polifoniese tekste. Die magdom studies en uiteenlopende lesings van hierdie tekste (in elke moontlike literatuurwetenskaplike benadering) is die duidelikste bewys dat hierdie tekste "begetters of readers" (soos Felperin, 1985, dit beskryf) is en dat hulle lesers tot verbeeldingryke en assosiatiewe lees en interpretasie uitlok.

\section{Gevolgtrekking}

'n Interessante waarneming wat uit hierdie profiel van die Modernisme na vore tree, is die ooreenkoms tussen die Wes-Europese Modernisme en die werk van die Sestigers in Afrikaans. 'n Mens sou kon beweer dat Sestig Afrikaans se Modernisme is. Die voor-die-hand-liggende bewys sou wees om die lysie aspekte 
(wat ook kodes genoem kan word) van die Sestigers se werk wat in Aspekte van die nuwe prosa van André P. Brink beskryf word, langs hierdie sosiokode van die Modernisme te plaas.

Hierdie saak kan nie in dié artikel uitgepluis word nie, trouens, dit regverdig 'n hele studie op sigself. Ek sou egter graag enkele ooreenkomste wou aantoon wat moontlik as prikkel vir 'n omvattende studie kon dien.

Volgens Brink (1975: 13) behels die vernuwing van die Sestigers drie aspekte:

“a) 'n uitgaan van die relatiewe as romangegewe, nie meer van die absolute nie;

b) 'n al meer inborende ontginning van alle aspekte van romanstruktuur - wat uiteindelik 'n algehele verandering in die 'epiese wêreld' gaan meebring;

c) 'n spesifieke nuwe hantering en beskouing van tyd as aktiewe struktuurfaktor in die roman."

Die ooreenkomste blyk alreeds hieruit. Wanneer Brink (1975: 17-23) oor Don Quijote skryf, is die aspek wat die sterkste beklemtoon word die siening dat dit 'n weergawe van 'n gerelativeerde innerlike werklikheid is: “... dis 'n kreatiewe aanval wat op die werklikheid geloods word, 'n verowering daarvan, 'n transformasie daarvan" en dis 'n wêreld waarin Sancho "alles glo en aan alles twyfel". In sy toeligting verwys Brink na verskeie modernistiese werke om die ervaring, die persepsie van verskillende werklikhede aan te toon, die relatiewe as gegewe en die strukturele gevolge van hierdie dinge vir die roman uit te lig.

Die gewildheid van die outsider-figuur in die Sestigerwerk (Die mugu, Die son struikel, Henry in Sewe dae en Adam Kadmon in Een vir Azazel), die spel met verwikkelde tydspatrone (18-44; Isis), die ontwikkeling van tegnieke wat met fokalisasie en vertelinstansie eksperimenteer (Houd-den-bek) en selfrefleksiewe elemente (Miskien nooit, 18-44) is enkele aspekte wat die Sestigerwerk by die konvensies van die Modernisme laat aansluit. In Afrikaans vermoed ek dat die modernistiese tradisie in die werk van sekere skrywers steeds voortduur (byvoorbeeld in die werk van Henriette Grove). Die filosofiese teelaarde van die Sestigers is Nietsche en Sartre, die fenomenologie en die eksistensialisme, net soos by die moderniste. Die liefde vir reis, vir die wegbeweeg van die eie, kom ook by albei groepe voor. Die Sestigers het 'n besondere band met Parys en almal probeer afstand kry op die eie omgewing en omstandighede al bevind hulle hulself nie altyd fisies op 'n ver plek nie (soos Breyten Breytenbach).

Hiermee wil ek net 'n terrein van studie aandui. Om werklik gemotiveerde 
stellings oor literêre strominge te maak, vereis deeglike en uitvoerige teksstudie, 'n studie van sosio-kulturele en filosofiese invloede asook 'n studie van literêrhistoriese faktore. Die Sestigerbeweging is al uit baie hoeke bespreek, maar miskien sal 'n studie van die ooreenkoms met en die invloed van die Modernisme op Sestig gegewens oplewer wat kontemporêre ontwikkelinge binne die Afrikaanse literatuur kan belig.

\section{Bibliografie}

Bradbury, M. \& McFarlane, J. (eds). 1976. Modemism. Harmondsworth: Penguin Books. Brink, André P. 1975. Aspekte van die nuwe prosa. Pretoria en Kaapstad: Academica. Brodkey, L. 1987. Modernism and the scenes of writing. College English, 49(4): 396-418, April.

Conrad, J. 1961. Heart of darkness. London: J.M. Dent \& Sons Ltd.

Faulkner, P. 1977. Modemism. London: Methuen.

Faulkner, P. (ed.). 1986. A modemist reader. London: B.J. Batsford.

Felperin, H. 1985. Beyond deconstruction. Oxford: Clarendon Press.

Fokkema, D \& Ibsch, E. (reds.). 1984. Het modemisme in de Europese letterkande. Amsterdam: De Arbeiderspers.

Fokkema, D.W. 1984. Literary history, modemism and postmodemism. (The Harvard University Erasmus Lectures, Spring, 1983.) Amsterdam: John Benjamins Publishing Company.

Friedling, S. 1973. Problems of perception in die modem novel: the representation of consciousness in works of Henry James, Gertrude Stein and William Faulkner. Part 1. (Thesis (Ph.D.) - University of Wisconsin.) (Fotokopie - University microfilms Inc.)

Joyce, James. 1947. Ulysses. London: John Lane the Bodley Head.

Joyce, James. 1983. The essential James Joyce. (With an introduction and notes by Harry Levin.) London: Granada.

Kenner, H. 1987. Modernism and what happened to it. Essays in criticism, 37(2): 97-109, April.

Kuna, Franz. 1976. The Janus-faced novel: Conrad, Musil, Kafka, Mann. (In Bradbury, M.S. \& McFarlane, J. (eds). 1976. Modemism. Harmondsworth: Penguin Books.)

Laffey, J.F. 1987. Cacophonic rites: modernism and postmodernism. Historical reflections, 14(1): $1-32$.

Levin, D.M. 1977. The novelhood of the novel: the limits of representation and the modernist discovery of presence. Chicago review, 28(4): 87-108.

Levin, Harry. 1966. What was modernism? (In Levin, H. Refractions. Essays in comparative literature. New York: Oxford University Press. p. 271-295.)

Levin, Harry. 1983. Editor's introduction. (In Joyce, James. The essential James Joyce. London: Granada. p. 9-19.)

Lodge, D. (ed.). 1972. 20th century literary criticism. London: Longman Group.

Miller, J.E. (ed.). 1972. Theory of fiction: Henry James. Lincoln: University of Nebraska Press.

Singal, D.J. 1987. Towards a definition of American modernism. American Quarterly, 39(1): 7-26. 
Stern, J.P. 1976. The theme of consciousness: Thomas Mann. (In Bradbury, M. \& McFarlane, J. Modemism. Harmondsworth: Penguin Books. p. 416-429.)

Woolf, Virginia. 1978. To the lighthouse. London: Everyman's Library.

Woolf, Virginia. 1972. Modem fiction. (In Lodge, D. (ed.). 20th century literary criticism. London: Longman Group. p. 86-91.)

\section{Geraadpleegde werke}

Adams, R.M. 1962. Surface and symbol. New York: Oxford University Press.

Baker, S. 1981. Narration: the writer's essential mimesis. The joumal of narrative technique, 11(3): 155-165, Fall.

Belscy, Catherine. 1980. Critical practice. London: Methuen.

Blamires, H. 1966. The Bloomsday book. London: Methuen.

Brée, G. \& Guiton, M. 1957. An age of fiction. The French novel from Gide to Camus. New Brunswick, New Jersey: Rutgers University Press.

Caserio, R.L. 1979. Plot, story and the novel. From Dickens and Poe to the modem period. Princeton, New Jersey: Princeton University Press.

Cazamian, L. 1963. A history of French literature. London: Oxford University Press.

Connor, S. 1987. The modern and the postmodern as history. Essays in criticism, 37(3): 181-192, July.

Derrida, J. 1976. On grammatology. Baltimore: Johns Hopkins University Press.

Derrida, J. 1978. Writing and difference. London: Routledge \& Kegan Paul.

Derrida, J. 1982. Sending: on representation. Social research.

Eco, U. 1984. Semiotics and the philosophy of language. Bloomington: Indiana University Press.

Eliot, T.S. 1949. Tradition and the individual talent. (In Stallman, R.W. Critiques and essays in criticism. New York: The Ronald Press Company. p. 377-383.)

Fletcher, J. \& Bradbury, M. 1976. The introverted novel. (In Bradbury, M. \& McFarlane, J. (eds). Modernism. Harmondsworth: Penquin. p. 394-415.)

Fokkema, D.W. \& Kunne-Ibsch, E. 1978. Theories of literature in the twentieth century. London: C. Hurst \& Company.

Fokkema, D.W. 1980. An interpretation of To the lighthouse: with reference to the code of modernism. PTL: A joumal for descriptive poetics and theory of literature, 4: 475-500.

Goldman, A. 1966. The Joyce pamadax. London: Routledge \& Kegan Paul.

Hutcheon, L. 1980. Narcissistic namative. London: Methuen.

Kettle, A. 1978. An introduction to the English novel. Vol II. London: Hutchinson \& Co. Lodge, D. 1976. The language of modernist fiction: metaphor and metonimy. (In Bradbury, M. \& McFarlane, J. (eds). Modemism. Harmondsworth: Penguin. p. 481496.)

McGee, P. 1987. Joyce's Nausea: style and representation in "Nausicaa". James Joyce quarterty, 24(3): 305-318.

Proust, Marcel. 1971. The past recaptured. (Newly translated by Andreas Mayor from the definitive French text.) Ncw York: Vintage Books.

Ryan, R. \& Van Zyl, S. (eds). 1982. An introduction to contemporary literary theory. Johannesburg: Ad. Donker. 
Sekula, A. 1978. Dismantling modernism, reinventing documentary (notes on the politics of representation). Massachusetts review, 19(4): 859-883.

Selden, R. 1985. A reader's quide to contemporary literary thought. Sussex: Harvester Press.

Stallman, R.W. 1949. Critiques and essays in criticism. New York: The Ronald Press Company.

Thornton, W. 1968. Allusions in Ulysses. Chapel Hill: University of North Carolina Press. Waugh, Patricia. 1984. Metafiction. The theory and practice of self-conscious fiction. London: Methuen.

West, P. 1963. The modem novel. London: Hutchinson \& Co.

Wilson, E. 1931. Axel's Castle. Glasgow: William Collins Sons.

Potchefstroomse Universiteit vir CHO 